\title{
Taxonomy and phylogeny of Aphanomycopsis bacillariacearum, a holocarpic oomycete parasitoid of the freshwater diatom genus Pinnularia
}

\author{
Anthony T. Buaya ${ }^{1} \cdot$ Bettina Scholz $^{2} \cdot$ Marco Thines $^{1,3}$ (D) \\ Received: 29 November 2020 / Revised: 1 January 2021 / Accepted: 4 January 2021 / \\ (C) The Author(s) 2021
}

\begin{abstract}
Investigations into simple holocarpic oomycetes are challenging, because of the obligate biotrophic nature of many lineages and the periodic presence in their hosts. Thus, despite recent efforts, still, the majority of species described remains to be investigated for their phylogenetic relationships. One of these species is Aphanomycopsis bacillariacearum, the type species of the genus Aphanomycopsis. Species of Aphanomycopsis are endobiotic holocarpic parasites of diverse hosts (e.g., diatoms, desmids, dinoflagellates). All species classified in this genus were assigned to it based on the presence of branching hyphae and the formation of two generations of zoospores, of which the first one is not motile. Originally, Aphanomycopsis with its type species, A. bacillariacearum, had been classified in the Saprolegniaceae. However, the genus has undergone multiple taxonomic reassignments (to Ectrogellaceae, Lagenidiaceae, and Leptolegniellaceae) in the past. To settle the taxonomy and investigate the phylogenetic placement of Aphanomycopsis, efforts were undertaken to isolate A. bacillariacearum from its original host, Pinnularia viridis and infer its phylogenetic placement based on nrSSU (18S) sequences. By targeted isolation, the diatom parasitoid was rediscovered from Heiðarvatn lake, Höskuldsstaðir, Iceland. Phylogenetic reconstruction shows that A. bacillariacearum from Pinnularia viridis is embedded within the Saprolegniales, and largely unrelated to both diatominfecting oomycetes in the Leptomitales (Ectrogella, Lagenisma) and those placed within the early-diverging lineages (Miracula, Diatomophthora) of the Oomycota.
\end{abstract}

Keywords Aphanomycopsis · Oomycetes · Diatom parasites · Taxonomy $\cdot$ Phylogeny

\section{Introduction}

Protist pathogens of photosynthetic eukaryotes are widely distributed in aquatic environments (Chambouve et al. 2019; Markussen Bjorbækmo et al. 2019; Hassett et al. 2019). These biotrophic parasites and parasitoids are diverse and

Section Editor: Marc Stadler

Marco Thines

m.thines@thines-lab.eu

1 Senckenberg Biodiversity and Climate Research Center, Senckenberganlage 25, D-60325 Frankfurt am Main, Germany

2 BioPol ehf, Marine Biotechnology, Einbúastig 2, 545 Skagaströnd, Iceland

3 Department of Biological Sciences, Institute of Ecology, Evolution and Diversity, Goethe-Universität Frankfurt am Main, Max-von-Laue Str. 13, D-60438 Frankfurt am Main, Germany infect wide varieties of hosts, especially marine and freshwater diatoms (Kühn 1998; Scholz et al. 2016; Guinder et al. 2017; Chambouve et al. 2019). However, the biology and ecological importance of these inconspicuous organisms are still widely unknown and understudied despite their abundance also during diatom blooms (Hanic et al. 2009; Thines et al. 2015; Hassett et al. 2019). Many of the oomycete parasitoids of freshwater diatoms were documented in studies from more than half a century ago (Karling 1942; Sparrow 1960) and were classified into various genera, mainly Aphanomycopsis (Scherffel 1925), Ectrogella (Zopf 1884), Lagenidium (Zopf 1878), and Olpidiopsis (Cornu 1872). Interest in these endobiotic parasitoids has resurged recently, with studies focusing on systematics (Buaya et al. 2017; Buaya and Thines 2019; Buaya and Thines 2020a; Buaya et al. 2020), axenic dual culture of host and parasite (Buaya et al. 2019b; Buaya et al. 2020), and environmental sequencing (Garvetto et al. 2018; Hassett et al. 2019). Despite these 
advances, the taxonomic affinities of most oomycete diatom parasitoids remain unresolved because of lacking sequence data, including also the type species of Aphanomycopsis, Aphanomycopsis bacillariacearum (Buaya and Thines 2020c). Aphanomycopsis was described by Scherffel in 1925 as a monotypic genus, characterized by non-septate holocarpic thalli, an aphanomyces-like pattern of zoospore development, and the production of multiple resting spores without apparent sexual organs. The species recurs seasonally in large freshwater diatoms, e.g., Pinnularia and Nitzschia (Scherffel 1925; Friedmann 1953; Kadlubowska 1970). The genus Aphanomycopsis has been subsequently emended and multiple holocarpic species with divergent hyphal morphology and host ranges were added (Tokunaga 1934; Canter 1949; Friedmann 1952; Martin 1975; Karling 1968; Boltovskoy 1984; Canter and Heaney 1984; Dick 2001), rendering the genus rather heterogeneous, despite its small size. In line with the heterogeneous nature of the genus, it was placed into various families over time, including Ectrogellaceae, Lagenidiaceae, Leptolegniellaceae, and Saprolegniaceae (Scherffel 1925; Tokunaga 1934; Karling 1942; Sparrow 1942; Dick 1971)

In order to resolve the phylogeny of the type species of Aphanomycopsis, attempts were made to isolate this organism from different freshwater habitats. While screening for holocarpic oomycete parasites of freshwater diatoms sampled from Heiðharvatn at Hoskuldsstaðhir in Iceland in the autumn of 2019, the species was rediscovered, and it was the aim of this study to document its life cycle and clarify its phylogenetic placement.

\section{Materials and methods}

\section{Collection, isolation, and characterization}

Diatom samples were collected from the lake Heiðharvatn, Hoskuldsstaðhir, Northeast Iceland (64 $54^{\prime} 12.54^{\prime \prime} \mathrm{N} 14^{\circ}$ $35^{\prime} 29.29 "$ W). Pinnularia viridis infected with oomycetes were collected in September 2019, using $20 \mu \mathrm{m}$ mesh plankton nets (Hydro-Bios, Kiel, Germany), horizontally towed. About $10 \mathrm{~mL}$ of phytoplankton concentrates were diluted, poured into several $15 \mathrm{~mL}$ petri-dishes, and screened for oomycete-infected diatoms using an inverted compound light microscope (Type AE31, Motic, Xiamen). Infected diatoms were individually picked using a $10 \mu \mathrm{L}$ micropipette (Brandt, Germany), rinsed multiple times in autoclaved deionized water, and transferred to $2 \mathrm{~mL}$ tubes containing $0.5 \mathrm{~mL}$ RNAlater solution (Invitrogen, Thermo Fisher, Lithuania) or $70 \%$ ethanol (VWR, France) for subsequent DNA extraction. Approximately 50 diatoms infected with Aphanomycopsis were collected this way for DNA extraction. Samples preserved in $70 \%$ ethanol were deposited in the herbarium collection of the Senckenberg Museum of Natural History (Herbarium Senckenbergianum, FR), Cryptogams Section, Frankfurt am Main, accession number FR-0046138. Morphological characterization of the parasite was done as described earlier (Buaya et al. 2020) using a compound light microscope (Imager2, Carl Zeiss Göttingen, Germany) with DIC, and photographs were taken using a Zeiss Axiocam MRc5 (Carl Zeiss, Göttingen, Germany). In addition, cellulose presence in the thallus wall of the parasitoids was tested using zinc iodine chloride (Carl Roth GmbH, Germany) solution. The identity of the diatom host was determined by light microscopy and 18S rRNA gene sequence barcoding as outlined for the oomycetes below. Axenic host and parasite dual culture of the isolated parasitoid were also attempted using different enrichment media, e.g., Guillard's f/2 medium (Guillard and Ryther 1962), DAM medium (GagneuxMoreaux et al. 2007), freshwater DM medium (Beakes et al. 1988), and WC medium (Guillard and Lorenzen 1972). However, all cultivation trials of $P$. viridis were unsuccessful, as were efforts to cultivate the parasitoid using common media, e.g., MEA (malt extract agar), PDA (potato dextrose agar), SAM (standard agar medium), and PYG (peptone yeast glucose agar).

\section{DNA extraction, PCR amplification, and phylogenetic analyses}

DNA extraction was performed using an innuPREP Plant DNA extraction Kit (Analytik Jena, Germany), as previously described (Buaya et al. 2017). Initially, isolates were centrifuged at $19000 \mathrm{~g}$ for $2 \mathrm{~min}$ at $22{ }^{\circ} \mathrm{C}$ to concentrate the cells. Subsequently, RNAlater was carefully removed using $1000 \mu \mathrm{l}$ pipette tips, and $400 \mu \mathrm{L}$ SLS buffer from the extraction kit was added. About $100 \mathrm{mg}$ of sterile $0.1 \mathrm{~mm}$ Silica Glass Beads (Carl Roth GmbH, Germany) were added into each 2 $\mathrm{mL}$ tubes (Sarstedt, Germany) and homogenized at $25 \mathrm{~Hz}$ for 25 min in a Retsch Mixer Mill MM 200 (Retsch GmbH, Germany). The PCR amplification of the nuclear encoding small subunit (nrSSU) was performed as described in Buaya et al. (2019a) using Mango-Taq DNA Polymerase (Bioline, UK) but with the $18 \mathrm{~S}$ primer pair EUK422-445 and EUK1422-1440_R (Wang et al. 2014). Positive amplicons were sent for sequencing to the laboratory center of the Senckenberg Biodiversity and Climate Research Centre, Frankfurt am Main (SBiK-F, Frankfurt, Germany) using the $18 \mathrm{~S}$ primer pairs used in the PCR. In addition, direct PCRs were also done as described in Buaya et al. (2019a). To obtain high-quality nrSSU sequences of the oomycete infecting $P$. viridis, PCR amplicons were also cloned. Initially, the PCR amplicons were purified using magnetic bead-based nucleic acid purification (AMPure XP, Beckman Coulter Inc., USA) as previously described (Buaya et al. 2020). Subsequently, PCR amplicons were diluted by a factor of 
ten, and the mixture was cloned into competent Escherichia coli using a StrataClone TA cloning kit (Agilent Technologies, Santa Clara, United States) following instructions of the manufacturer. Single bacterial colonies were picked into $20 \mu \mathrm{L}$ molecular grade water (Life Technologies, USA) and colony PCR was carried out with the Mango DNA Polymerase using M13-F and M13-R plasmid primers with amplification conditions set to an initial denaturation at $96{ }^{\circ} \mathrm{C}$ for $10 \mathrm{~min}, 36$ cycles at $96^{\circ} \mathrm{C}$ for $20 \mathrm{~s}, 56^{\circ} \mathrm{C}$ for $20 \mathrm{~s}$, and $72{ }^{\circ} \mathrm{C}$ for $60 \mathrm{~s}$, and concluding with a final elongation at $72{ }^{\circ} \mathrm{C}$ for $10 \mathrm{~min}$. Amplicons were sent for sequencing to the laboratory center of the Senckenberg Biodiversity and Climate Research Centre (Frankfurt am Main, Germany) using M13 (M13-F, M13-R), T3, and T7 plasmid primers. The resulting sequences obtained were edited using Geneious (version 5.6), and the assembled sequences of A. bacillariacearum were aligned together with reference sequences of various members of the Saprolegniales (Table 1), using mafft, version 7 (Katoh and Standley 2013), employing the Q-INS-I algorithm. Minimum evolution phylogenetic inference with 500 bootstrap replicates was computed using MEGA7 (Kumar et al. 2016) with pairwise deletion, the Tamura-Nei substitution model, and all other parameters set to default. Other phylogenetic analyses were done on the TrEase webserver (http://thines-lab.senckenberg.de/trease/) using RAxML (Stamatakis 2014) for maximum likelihood inference with 1000 bootstrap replicates. Bayesian inference was done on the same server using MrBayes, version 3.2 (Ronquist et al. 2012) and 5 million generations, while other parameters were set to default. The consensus partial $18 \mathrm{~S}$ (nrSSU) sequence obtained in this study was deposited in GenBank under the accession number MW307772.

\section{Results}

\section{Parasite screening and detection}

Diatoms collected during autumn 2019 from Heiðharvatn at Hoskuldsstaðhir on Iceland were detected to contain Pinnularia viridis with biotrophic oomycete infections. About $10 \%$ of the $P$. viridis individuals screened from Heiðharvatn were infected by Aphanomycopsis bacillariacearum. All samples were further incubated for 34 weeks with addition of $\mathrm{f} / 2$ medium and kept at controlled conditions as previously described (Buaya et al. 2019b). This allowed further propagation of the host diatom to increase chances of re-isolating the target pathogen. These samples were screened daily, and after 3-4 weeks, $P$. viridis reappeared in all samples. Infections were observed to increase in parallel to the abundance of $P$. viridis cells, but disappeared again quickly, lasting only 1-2 weeks, after devastating almost all $P$. viridis individuals present. Epithemia turgida, Cymbella gastroides, Nitzschia sigmoidea, and Synedra spp., which were also reported to be host for A. bacillariacearum (Karling 1942; Sparrow 1960), were cooccurring with the infected individuals of $P$. viridis, but no individuals of these species were detected to be parasitized throughout the examination period. Attempts to establish a stable dual culture containing host and parasite were unsuccessful.

\section{Morphology and lifecycle observations}

The development of the parasitoid isolated in this study, from the start of infection until zoospore release, was documented using several specimens of infected $P$. viridis. The morphology and life cycle of the $P$. viridis parasitoid (Fig. 1a-j) agrees well with previous descriptions of Aphanomycopsis bacillariacearum (Scherffel 1925; Friedmann 1953).

The life cycle of this parasite started when an encysted spore attached on the outer surface of the host frustule germinated (Fig. 1a), producing a very fine, needle-like tube, penetrating at the girdle bands, and growing into the protoplasm usually at the central nodule, close to the nucleus. Once established, the thallus rapidly grew, causing gradual degradation of the host phaeoplasts that normally fill the entire cell in girdle view, reducing them into golden green or light brown to slightly chestnut colored, elongated or fragmented residues. These were lining at the center (girdle view) (Fig. 1a) or at the periphery of the girdle bands (valve view), while the parasitoid extended to the polar nodules (Fig. 1b). Subsequently, the host protoplasm began to disintegrate around the undifferentiated thalli which contained scattered globular droplets and were surrounded by a thin, colorless wall (Fig. 1b, c). The droplets gradually disappeared as the thalli elongated, and the colorless thallus wall slightly thickened. Normally, a single host contained one unbranched or branched non-septate holocarpic hyphal thallus of 4-12 $\mu \mathrm{m}$ in diameter (Fig. 1d), but occasionally $2-3$ that were tightly compacted within the frustule and variable in length were also observed. The thalli did not cause hypertrophy nor disintegrate the valves. As the thalli matured, one to several slightly tapering slender discharge tubes began to form per thallus. Exit tubes were normally $180-240 \mu \mathrm{m}$ long, with a diameter of $4-8 \mu \mathrm{m}$, and with a thickened base (Fig. 1f). After some time, the content of the sporangia slowly moved into the tip of the discharge tube, forming a circular mass of aplanospores at the orifice. Subsequently, these rapidly differentiated into primary cysts of $8-12 \mu \mathrm{m}$ in diameter in variable numbers (Fig. $1 \mathrm{~g}$ ). After encystation, a short period of quiescence followed. Subsequently, each of the cysts developed a single discharge papilla of 3-5 $\mu \mathrm{m}$ in diameter that forms in parallel with the development of the secondary zoospores. The cysts then germinated almost simultaneously to produce biflagellate secondary zoospores, which were 10-12 $\mu \mathrm{m}$ long and 7-8 $\mu \mathrm{m}$ 
Table 1 Sequence data used in this study

\begin{tabular}{|c|c|c|c|}
\hline Genus & Species & GenBank accession \# & Citation \\
\hline Pythiopsis & intermedia & KP098377 & Steciow et al. (2014) \\
\hline Pythiopsis & terrestris & KP098379 & Steciow et al. (2014) \\
\hline Protoachlya & paradoxa & KP098375 & Steciow et al. (2014) \\
\hline Pythiopsis & cymosa & AJ238657 & Dick et al. (1999) \\
\hline Pythiopsis & humphreyana & KP098376 & Steciow et al. (2014) \\
\hline Saprolegnia & parasitica & XR001099850 & Jiang et al. (2013) \\
\hline Saprolegnia & parasitica & AB086899 & Khomvilai et al. (2005) \\
\hline Achlya & apiculata & AJ238656 & Dick et al. (1999) \\
\hline Newbya & dichotoma & KP098364 & Steciow et al. (2014) \\
\hline Achlya & ornata & KP098365 & Steciow et al. (2014) \\
\hline Aplanes & treleaseanus & КР098363 & Steciow et al. (2014) \\
\hline Thraustotheca & clavata & KP098372 & Steciow et al. (2014) \\
\hline Achlya & bisexualis & M32705 & Gunderson et al. (1987) \\
\hline Achlya & debaryana & KP098371 & Steciow et al. (2014) \\
\hline Thraustotheca & clavata & KP098373 & Steciow et al. (2014) \\
\hline Leptolegnia & caudata & KP098368 & Steciow et al. (2014) \\
\hline Leptolegnia & chapmanii & AJ238661 & Dick et al. (1999) \\
\hline Achlya & sparrowii & KP098380 & Steciow et al. (2014) \\
\hline Leptolegnia & sp. & AJ238662 & Dick et al. (1999) \\
\hline Aphanomyces & sp. & FJ794896 & Wolinska et al. (2009) \\
\hline Aphanomyces & sp. & FJ794897 & Wolinska et al. (2009) \\
\hline Aphanomyces & astaci & XR717099 & Unpublished \\
\hline Aphanomyces & invadans & DQ403202 & Sosa et al. (2007) \\
\hline Aphanomyces & invadans & XR608067 & Unpublished \\
\hline Aphanomycopsis & bacilliacearum & MW307772 & This study \\
\hline Aquastella & attenuata & KF294792 & Molloy et al. (2014) \\
\hline Aquastella & acicularis & KF294791 & Molloy et al. (2014) \\
\hline Uncultured & & KP685316 & Jiang et al. (2016) \\
\hline Lagenisma & coscinodisci & KT273921 & Thines et al. (2015) \\
\hline Chlamydomyzium & sp. & EU271965 & Beakes et al. (2006) \\
\hline Blastulidium & paedophthorum & KR869808 & Duffy et al. (2015) \\
\hline Apodachlya & brachynema & AJ238663 & Dick et al. 1999 \\
\hline Chlamydomyzium & sp. & JQ031283 & Beakes et al. (2014) \\
\hline Atkinsiella & dubia & $\mathrm{AB} 284575$ & Muraosa et al. (2009) \\
\hline Bolbea & parasitica & MN688695 & Buaya and Thines (2020b) \\
\hline Myzocytiopsis & humicola & KT257375 & Unpublished \\
\hline Myzocytiopsis & glutinospora & KT257371 & Unpublished \\
\hline Myzocytiopsis & venatrix & EU271960 & Beakes et al. (2006) \\
\hline Lagenidium & caudatum & EU271961 & Beakes et al. (2006) \\
\hline Lagenidium & giganteum & KT257332 & Unpublished \\
\hline Pythium & glomeratum & HQ643543 & Robideau et al. (2011) \\
\hline Phytopythium & megacarpum & HQ643388 & Robideau et al. (2011) \\
\hline Phytopythium & vexans & HQ643400 & Robideau et al. (2011) \\
\hline Halocrusticida & parasitica & $\mathrm{AB} 284576$ & Muraosa et al. (2009) \\
\hline Halocrusticida & baliensis & $\mathrm{AB} 284578$ & Muraosa et al. (2009) \\
\hline Halodaphnea & panulirata & $\mathrm{AB} 284574$ & Muraosa et al. (2009) \\
\hline Haliphthoros & milfordensis & AB178868 & Sekimoto et al. (2007) \\
\hline Haliphthoros & sp. & $\mathrm{AB} 284579$ & Muraosa et al. (2009) \\
\hline Pontisma & lagenidioides & MK253530 & Buaya et al. (2020) \\
\hline Diatomophthora & gillii & MH971238 & Buaya et al. (2017) \\
\hline Diatomophthora & gillii & MH971239 & Buaya et al. (2017) \\
\hline Diatomophthora & drebesii & MF926410 & Thines et al. (2015) \\
\hline Anisolpidium & ectocarpii & KU764786 & Gachon et al. (2015) \\
\hline
\end{tabular}

in diameter (Fig. 1h, red arrows). These swam in a zigzag pattern for a few minutes before coming to a rest. One to several oospores were observed to develop within some thalli similar to Chlamydomyzium. The oospores were spherical to broadly ovoid, 20-30 $\mu \mathrm{m}$ in diameter, and surrounded by a smooth, colourless wall (Fig. 1e), which was thinner than in 


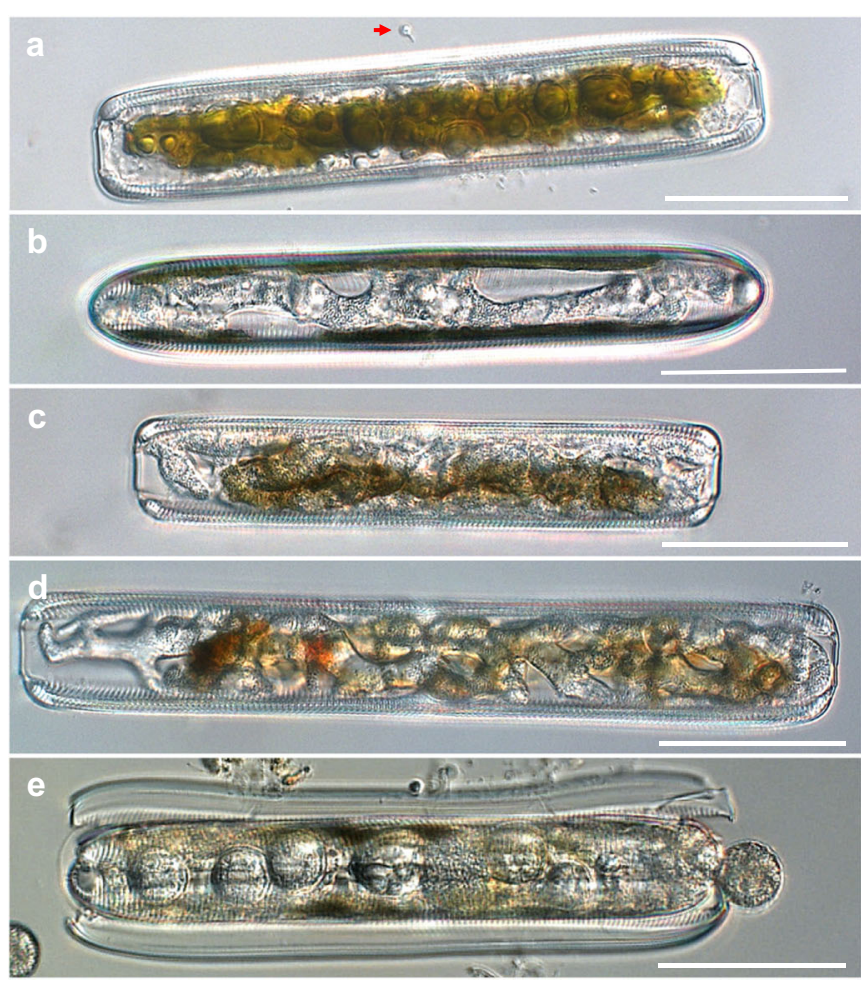

Fig. 1 DIC light micrographs of Aphanomycopsis bacillariacearum at different life cycle stages on Pinnularia viridis. a Early infection of $P$. viridis, with developing endobiotic holocarpic thalli. An encysted zoospore is marked by a red arrow; $\mathbf{b}$, $\mathbf{c}$ elongating thallus at early (b) and intermediate stage (c) of developing thallus surrounded by light brown-green colored phaeoplast residues; d highly branched nonseptate mature thallus; e multiple spherical resting spores (oospores) with eccentric globules and refractive droplets surrounded by a smooth,

Saprolegniaceae. The oospores usually contained eccentric globules or tiny refractive droplets, and probably developed parthenogenetically. Oospore germination was not observed. The entire parasitoid thallus and especially the thickened section of the discharge tube base were tested positive for the presence of cellulose, as evidenced by a strong violet to blueish colour after staining with a solution of zinc iodine chloride (Fig. 1j).

\section{Phylogenetic placement}

In the phylogenetic reconstructions inferred from partial nrSSU rRNA gene sequences (Fig. 2), Aphanomycopsis bacillariacearum was resolved as member of the Saprolegniales together with Aquastella, Aphanomyces, and various members of the Saprolegniaceae. It formed the sister to Aphanomyces in Minimum Evolution, while no support for this or an alterantive placement was obtained in Maximum Likelihood and Bayesian Inference. However, the placement of A. bacilliacearum in Saprolegniales received low support in Minimum Evolution and Maximum Likelihood analyses, but maximum support in Bayesian Inference.
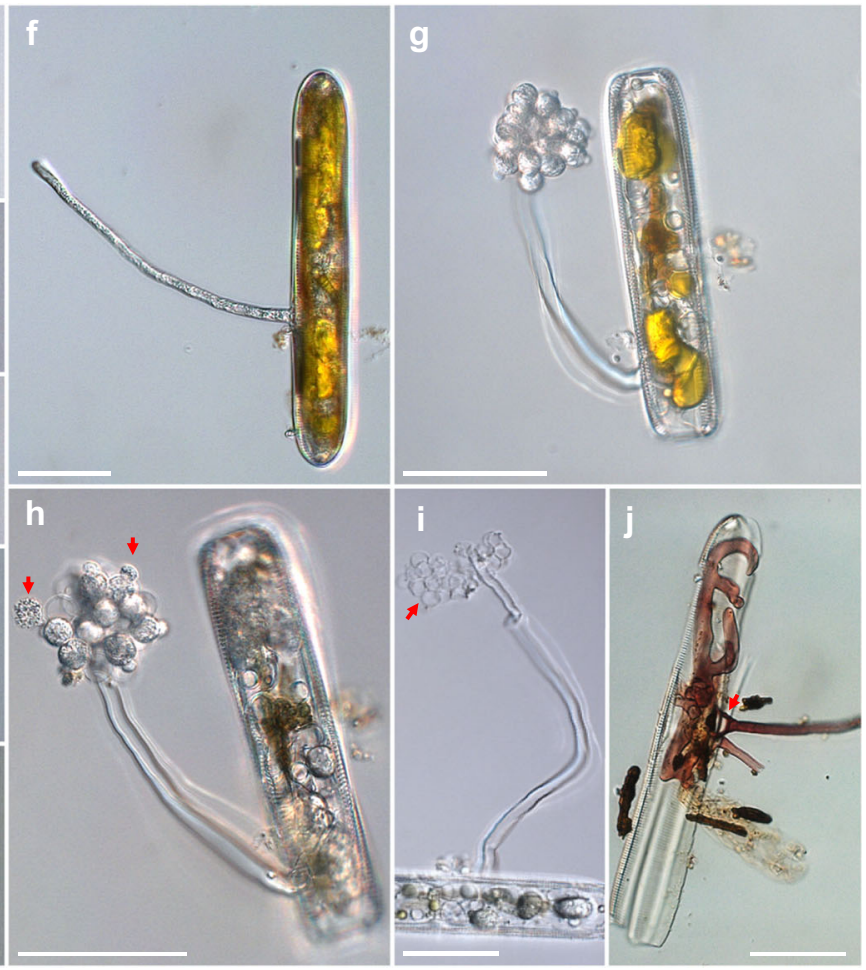

colourless, thick wall; $\mathbf{f}$ elongating discharge tube; $\mathbf{g}$ fully formed mass of primary aplanospores at the orifice of the discharge tube; $\mathbf{h}$ mature zoospores emerging individually from cysts, squeezing through the discharge papillae (red arrows) in achlya-like pattern; $\mathbf{i}$ cluster of empty zoospores cysts (red arrow); $\mathbf{j}$ zinc iodine stained empty thallus of A. bacillariacearum with a pronounced Spreizapparat on the base of the discharge tube (red arrow). Bar $=50 \mu \mathrm{m}$ in all pictures

\section{Discussion}

Oomycete parasites of diatoms are diverse, belonging to six different genera-Aphanomycopsis (Scherffel 1925), Diatomophthora (Buaya and Thines 2020a), Ectrogella (Zopf 1884), Lagenidium (Zopf 1878), Lagenisma (Drebes 1966), and Miracula (Buaya et al. 2017). So far, only a handful of these holocarpic endoparasitoids have sequence data available (e.g., D. drebesii, E. bacillariacearum, L. coscinodisci), rendering the phylogenetic placement of most species unresolved and their taxonomic assignment unconfirmed (Buaya and Thines 2020c). This includes five species of Ectrogella (E. monostoma, E. gomphonematis, E. eunotiae, E. licmophorae, E. eurychasmoides), three species of Lagenidium (L. cyclotellae, L. brachystomum, L. enecans), and A. bacillariacearum (Zopf 1884; Scherffel 1925; Friedmann 1952; Feldmann and Feldmann 1955).

However, A. bacillariacearum remains the only genus type among diatom-infecting genera that has not been investigated in terms of molecular phylogeny. This species is widespread in freshwater environments and has been reported from a variety of pennate diatoms (Pinnularia viridis, Epithemia turgida, Cymbella gastroides, Nitzschia sigmoidea, Synedra 
Fig. 2 Molecular phylogeny based on Minimum Evolution analysis inferred from partial nrSSU rRNA gene sequences. Numbers on branches denote bootstrap values from Minimum Evolution, Maximum Likelihood, and Bayesian Inference, in the respective order. A dash "-" indicates less than $60 \%$ bootstrap support or less than 0.8 posterior probability for the respective node

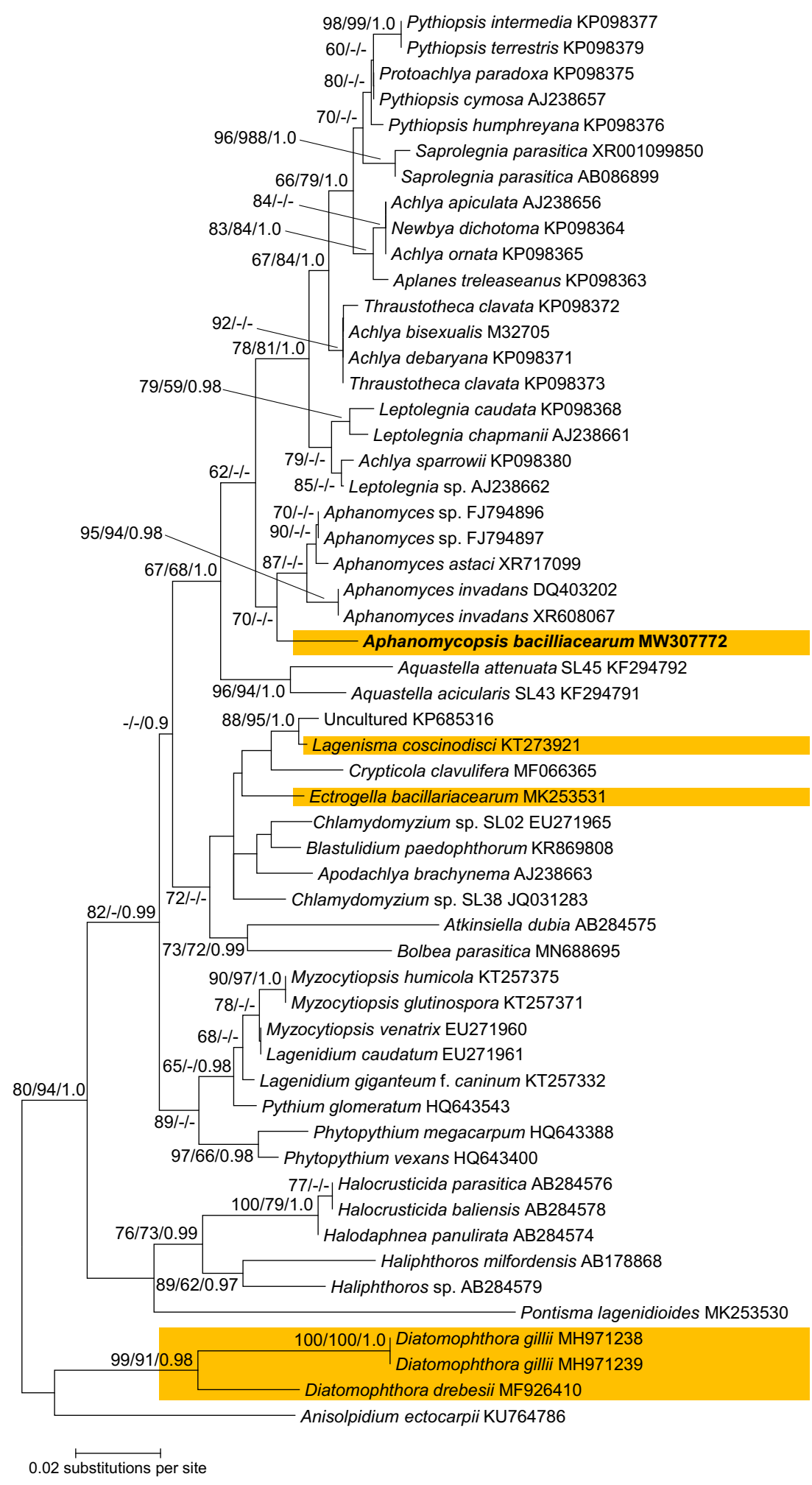

spp.) as potential hosts (Scherffel 1925; Sparrow 1933; Sparrow 1935; Sparrow 1936; Friedmann 1953).

The genus Aphanomycopsis was introduced by Scherffel (1925), as a monotypic genus to accommodate his newly described holocarpic diatom parasitoid A. bacillariacearum.
This genus was originally placed in the Saprolegniaceae, because of similarities to Ectrogella and Aphanomyces in terms of morphology and zoosporogenesis (Scherffel 1925). Subsequent investigators accepted this taxonomic assignment (e.g., Sparrow 1933). However, Tokunaga (1934) disagreed 
and reassigned the organism into Lagenidiaceae, based on his isolates having a septate thallus, no Spreizapparat on the discharge tube base, and a resting spore formation similar to Lagenidium. This placement was not accepted by Coker and Matthews (1937), who included Aphanomycopsis in Ectrogellaceae. Karling (1942) discussed the findings of Tokunaga (1934) and accepted a provisional placement of Aphanomycopsis in the Ectrogellaceae together with Ectrogella, Eurychasma, and Eurychasmidium, as he concluded that Tokunaga (1934) had probably seen an organism different from the one of Scherffel (1925). Similarly, Sparrow (1942, 1943) placed Aphanomycopsis and subsequently also Pythiella (Sparrow 1960) in Ectrogellaceae. Later, Karling added two plant saprophytic and keratinophilic species, A. saprophytica and A. punctata (Karling 1968) to the genus. Dick (1971) placed Aphanomycopsis into the new family Leptolegniellaceae and included four species (A. bacillariacearum, A. desmidiella, A. saprophytica, and A. punctata) in the genus. Karling (1981) followed the assignment of Dick (1971), accepting Aphanomycopsis in Leptolegniellaceae. Dick (2001) recognized the six genera Aphanodictyon, Brevilegniella, Leptolegniella, Nematophthora, Aphanomycopsis, and Cornumyces in Leptolegniellaceae. However, he regarded the taxonomic placement of Aphanomycopsis as uncertain, due to the lack of a separable endospore membrane, which is a distinctive character of the Leptolegniellaceae sensu stricto (Dick 2001).

The isolate investigated in this study agrees well with the original description of Scherffel (1925), in terms of both morphology and diatom host. To fix the application of the name, Fig. 42 of Tafel 2 drawn by Scherffel for the original description of $A$. bacillariacearum in Archiv für Protistenkunde 52 (1925) on page 14 is designated as lectotype here (MBT395398), and the specimen collected in September 2019 in Iceland by A.T. Buaya and M. Thines deposited in the Herbarium Senckenbergianum under the accession number FR-0046138 is designated as epitype here (MBT395399). The observation that $A$. bacillariacearum produces broadly unbranched to branched, nonseptate thalli with a thickwalled Spreizapparat like Ectrogella bacillariacearum, but unlike Lagenidium, with zoospore production resembling Aphanomyces (Scherffel 1925; Sparrow 1933, 1960), is confirmed in this study and support its placement in Saprolegniales. In line with this, the phylogenetic reconstruction of this study revealed Aphanomycopsis as a member of the order Saprolegniales, with affinities to the genus Aphanomyces. Thus, it might be considered a member of the Verrucalvaceae, but support for the grouping with Aphanomyces was low, necessitating multigene phylogenies for testing this hypothesis. Considering the significant variation in thallus arrangement (eucarpic and holocarpic), lifestyles (saprotrophic, necrotrophic, and obligate biotrophic), and the various host groups observed (plants, animals, and straminipilous organisms) in the species with aphanomyceslike spore production (Karling 1968, Gaulin et al. 2007; Diéguez-Uribeondo et al. 2009), a detailed investigation of these organisms might give important insights into thallus evolution and host specificity in oomycetes.

The sexual cycle of $A$. bacillariacearum is not yet fully understood, but the species is known to produce hyaline resting spores that have a thinner wall than members of the Saprolegniaceae, and which probably originate from parthenogenesis (Scherffel 1925; Dick 2001). Thus, it is highly likely that the specimens from Japan investigated by Tokunaga (1934) did not belong to A. bacillariacearum. Probably, his isolate, the isolate of West and West (1906) from the desmid algae Pleurotaenium ehrenbergii, and Friedmann's (1952) isolate from the diatom Pinnularia viridis, which also contains transverse thallus septations correspond to a novel group of peronosporalean oomycetes.

In the absence of sequence data for other members of Aphanomycopsis sensu Dick (2001), it is uncertain, if the generic placement is correct for Aphanomycopsis entophyta (Dick 2001), A. saprophyticus (Karling 1968), A. punctatus (Karling 1968), A. cryptica (Canter and Heaney 1984), and A. peridiniella (Boltovskoy 1984), as well as A. desmidiella (Canter 1949) and A. sexualis (Martin 1975). The collective host range of these species includes diatoms (A. bacillariacearum), filamentous algae (A. entophyta), desmid algae (A. desmidiella), dinoflagellates (A. cryptica, A. peridiniella), insects (A. sexualis), and extends to keratinophilic (A. punctatus) and plant saprophytic species (A. saprophyticus) (Sparrow 1960; Dick 2001). Given this diverse range of hosts and substrates, as well as differences in zoospore formation, it is highly probable not all are closely related to Aphanomycopsis and that the genus will need substantial revision in the future.

Acknowledgments MT gratefully acknowledges a DAAD travel award that seeded the collaboration leading to the present study. According to a recent recommendation by Thines et al. (2020), scientific names of all ranks are set in italics.

Authors' contributions ATB and MT conceived the study; ATB, BS, and MT conducted fieldwork; ATB carried out the experiments; ATB and MT analyzed the data and generated the figures; ATB and MT wrote the manuscript, with contributions from BS.

Funding Open Access funding enabled and organized by Projekt DEAL. ATB is thankful to Katholischer Akademischer Ausländer Dienst (KAAD) for a 3-year doctoral fellowship, Stiftung zur Förderung der internationalen Beziehungen der Goethe-Universität Frankfurt am Main, and the Senckenberg Biodiversität und Klima Forschungszentrum (SBiK-F) for add-on scholarships. MT is supported by LOEWE in the framework of the Centre for Translational Biodiversity Genomics.

Data availability Sequence data have been deposited in GenBank under the accesion number MW307772. The epitye of Aphanomycopsis 
bacillariacearum, which is part of the same gathering that was used to produce the sequence data, has been deposited in the Herbarium Senckenbergianum (FR) under the accession number FR-0046138.

\section{Compliance with ethical standards}

Competing interests The authors declare that they have no competing interests.

Ethics approval and consent to participate Not applicable.

\section{Consent for publication Not applicable.}

Open Access This article is licensed under a Creative Commons Attribution 4.0 International License, which permits use, sharing, adaptation, distribution and reproduction in any medium or format, as long as you give appropriate credit to the original author(s) and the source, provide a link to the Creative Commons licence, and indicate if changes were made. The images or other third party material in this article are included in the article's Creative Commons licence, unless indicated otherwise in a credit line to the material. If material is not included in the article's Creative Commons licence and your intended use is not permitted by statutory regulation or exceeds the permitted use, you will need to obtain permission directly from the copyright holder. To view a copy of this licence, visit http://creativecommons.org/licenses/by/4.0/.

\section{References}

Beakes GW, Canter HM, Jaworski GHM (1988) Zoospore ultrastructure of Zygorhizidium affuens and Z. planktonicum, two chytrids parasitizing the diatom Asterionellaformosa. Can J Bot 66:1054-1067

Beakes GW, Glockling SL, James TY (2006) The phylogeny of oomycete nematode pathogens. In: Meyer W, Price C (eds) Proceedings of the 8th International Mycological Congress. Medimond International, Bologna, pp 7-14

Beakes GW, Glockling SL, James TY (2014) A new oomycete species parasitic in nematodes, Chlamydomyzium dictyuchoides sp. nov.: developmental biology and phylogenetic studies. Fungal Biol 118: 527-543

Boltovskoy A (1984) Relacion huesped-parasito entre el quiste de Peridinium willei y el oomycete Aphanomycopsis peridiniella $\mathrm{n}$. sp. Limnobios 2:635-645

Buaya AT, Ploch S, Hanic L, Nam B, Nigrelli L, Kraberg A, Thines M (2017) Phylogeny of Miracula helgolandica gen. et sp. nov. and Olpidiopsis drebesii sp. nov. two basal oomycete parasitoids of marine diatoms, with notes on the taxonomy of Ectrogella-like species. Mycol Prog 16:1041-1050

Buaya AT, Thines M (2019) Miracula moenusica, a new member of the holocarpic parasitoid genus from the invasive freshwater diatom Pleurosira laevis. FUSE 3:19-33

Buaya AT, Ploch S, Thines M (2019a) Rediscovery and phylogenetic placement of Olpidiopsis gillii (de Wildeman) Friedmann, a holocarpic oomycete parasitoid of freshwater diatoms. Mycosc 60: $141-146$

Buaya AT, Kraberg A, Thines M (2019b) Dual culture of the oomycete Lagenisma coscinodisci Drebes and Coscinodiscus diatoms as a model for plankton/parasite interactions. Helgoland Mar Res 73:2

Buaya AT, Thines M (2020a) Diatomophthoraceae - a new family of olpidiopsis-like diatom parasitoids largely unrelated to Ectrogella. FUSE 5:113-118
Buaya AT, Thines M (2020b) Bolbea parasitica gen. et sp. nov., a cultivable holocarpic parasitoid of the early-diverging Saprolegniomycetes. FUSE 6:129-137

Buaya AT, Thines M (2020c) An overview on the biology and phylogeny of the early-diverging oomycetes. Philipp J Syst Biol 14:1-20

Buaya AT, Ploch S, Kraberg A, Thines M (2020) Phylogeny and cultivation of the holocarpic oomycete Diatomophthora perforans comb. nov., an endoparasitoid of marine diatoms. Mycol Prog 19: 441-454

Canter HM (1949) On Aphanomycopsis bacillariacearum Scherffel, A. desmidiella n. sp., and Ancylistes spp. in Great Britain. Tr Brit Mycol Soc 32:162-170

Canter HM, Heaney SI (1984) Observations on zoosporic fungi of Ceratium spp. in lakes of the English Lake District; importance for phytoplankton population dynamics. New Phytologist 97:601-612

Chambouve A, Monier A, Maguire F, Itoïz S, del Campo J, Elies P, Edvardsen B, Eikreim W, Richards TA (2019) Intracellular infection of diverse diatoms by an evolutionary distinct relative of the fungi. Curr Biol 29:4093-4101

Coker WC, Matthews VD (1937) Blastocladiales, Monoblepharidales, Saprolegniales. North Am Fl 2:1-76

Cornu M (1872) Monographie des Saprolegniees, etude physiologique et systematique. Ann Sci. Nat Bot 15:1-198

Dick MW (1971) Leptolegniellaceae fam. nov. Trans Brit Mycol Soc 57: 417-425

Dick MW (2001) Straminipilous Fungi. Kluwer, Netherlands

Dick MW, Vick MC, Gibbings JG, Hedderson TA, Lopez-Lastra CC (1999) 18S rDNA for species of Leptolegnia and other Peronosporomycetes: justification for the subclass taxa Saprolegniomycetidae and Peronosporomycetidae and division of the Saprolegniaceae sensu lato into the Leptolegniaceae and Saprolegniaceae. Mycol Res 103:1119-1125

Diéguez-Uribeondo J, García MA, Cerenius L, Kozubíková E, Ballesteros I, Windels C, Weiland J, Kator H, Söderhäll K, Martín MP (2009) Phylogenetic relationships among plant and animal parasites, and saprotrophs in Aphanomyces (Oomycetes). Fungal Gen Biol 46:365-376

Drebes G (1966) Ein parasitischer Phycomycet (Lagenidiales) in Coscinodiscus. Helgol Wiss Meeresunters 13:426-435

Duffy MA, James TY, Longworth A (2015) Ecology, virulence, and phylogeny of Blastulidium paedophthorum, a widespread brood parasite of Daphnia spp. Appl Env Microbiol 81:5486-5496

Feldmann J, Feldmann G (1955) Observations sur quelques Phycomycetes marins nouveaux ou peu connus. Rev Mycol 20: 231-251

Friedmann I (1952) Über neue und wenig bekannte auf Diatomeen parasitierende Phycomyceten. Öst Bot Z 99:173-219

Friedmann I (1953) Eine neue Chytridiale, Chytridium Surirellae n. sp. Öst Bot Z 100:5-7

Gachon CM, Fletcher KI, Badis Y, van West P, Mueller DG (2015) The pathogens of brown algae Anisolpidium ectocarpii and Anisolpidium rosenvingei define a new class of marine anteriorly uniciliate oomycetes. Europ J Phycol 50(s1):25-26

Gagneux-Moreaux S, Moreau C, Gonzalez JL, Cosson RP (2007) Diatom artificial medium (DAM): a new artificial medium for the diatom Haslea ostrearia and other marine microalgae. J Appl Phycol 19:549-556

Garvetto A, Nézan E, Badis Y, Bilien G, Arce P, Bresnan E, Gachon CMM, Siano R (2018) Novel widespread marine oomycetes parasitising diatoms, including the toxic Genus Pseudo-nitzschia: genetic, morphological, and ecological characterisation. Front Microbiol 9:2918

Gaulin E, Jacquet C, Bottin A, Dumas B (2007) Root rot disease of legumes caused by Aphanomyces euteiches. Mol P1 Pathol 8:539548 
Gunderson JH, Elwood H, Ingold A, Kindle K, Sogin ML (1987) Phylogenetic relationships between chlorophytes, chrysophytes, and oomycetes. PNAS 84:5823-5827

Guillard RRL, Lorenzen CJ (1972) Yellow-green algae with chlorophyllide C. J Phycol 8:10-14

Guillard RR, Ryther JH (1962) Studies of marine planktonic diatoms: I. Cyclotella nana Hustedt, and Detonula confervacea (Cleve) Gran. Can J Microbiol 8:229-239

Guinder VA, Carcedo MC, Buzzi N, Molinero JC, Abbate CL, Melisa FS, Florencia B, Kühn S (2017) Ephemeral parasitism on blooming diatoms in a temperate estuary. Mar Freshwater Res 69:128-133

Hanic LA, Sekimoto S, Bates SS (2009) Oomycete and chytrid infections of the marine diatom Pseudo-nitzschia pungens (Bacillariophyceae) from Prince Edward Island, Canada. Canadian Journal of Botany 87:1096-1105

Hassett BT, Thines M, Buaya A, Ploch S, Gradinger R (2019) A glimpse into the biogeography, seasonality, and ecological functions of arctic marine Oomycota. IMA Fungus 10:6

Jiang RH, de Bruijn I, Haas BJ, Belmonte R, Lobach L, Christie J, van den Ackerveken G, Bottin A, Bulone V, Diaz-Moreno SM, Dumas B, Fan L, Gaulin E, Govers F, Grenville-Briggs LJ, Horner NR, Levin JZ, Mammella M, Meijer HJ, Morris P, Nusbaum C, Oome S, Phillips AJ, van Rooyen D, Rzeszutek E, Saraiva M, Secombes CJ, Seidl MF, Snel B, Stassen JH, Sykes S, Tripathy S, van den Berg H, Vega-Arreguin JC, Wawra S, Young SK, Zeng Q, DieguezUribeondo J, Russ C, Tyler BM, van West P (2013) Distinctive expansion of potential virulence genes in the genome of the oomycete fish pathogen Saprolegnia parasitica. PLoS Genet 9: e1003272

Jiang R, Wang JX, Yu KC, Liu MH, Shi G, Liu XZ (2016) Microeukaryotic diversity in the surface layer of sediments from the East China Sea. Evol Ecol Res 17:125-140

Kadlubowska JZ (1970) Podochytrium clavatum Pfitzer and Aphanomycopsis bacillariacearum Scherffel new species in the Polish flora. Act Mycologica 6:55-57

Karling JS (1942) The simple holocarpic biflagellate Phycomycetes. Published by Karling JS, New York

Karling JS (1968) Zoosporic fungi of Oceania. II. Two saprophytic species of Aphanomycopsis. Mycologia 60:271-284

Karling JS (1981) Predominantly holocarpic and eucarpic simple biflagellate Phycomycetes. J. Kramer, Stuttgart

Katoh K, Standley DM (2013) MAFFT multiple sequence alignment software version 7: improvements in performance and usability. Mol Biol Evol 30:772-780

Khomvilai C, Karita S, Kashiwagi M, Yoshioka M (2005) Fungicidal effects of sodium hypochlorite solution on Saprolegnia isolated from eggs of chum salmon Oncorhynchus keta. Fish Sci 71:11881190

Kumar S, Stecher G, Tamura K (2016) MEGA7: Molecular evolutionary genetics analysis version 7.0 for bigger datasets. Mol Biol Evol 33: 1870-1874

Kühn SF (1998) Infection of Coscinodiscus spp. by the parasitoid nanoflagellate Pirsonia diadema: II. Selective infection behaviour for host species and individual host cells. J Plankton Res 20:443454

Markussen Bjorbækmo MF, Evenstad A, Røsæg LL, Krabberød AK, Logares R (2019) The planktonic protist interactome: where do we stand after a century of research? ISME J 14:544-559

Martin WW (1975) Aphanomycopsis sexualis, a new parasite of midge eggs. Mycologia 67:923-933

Molloy DP, Glockling SL, Siegfried CA, Beakes GW, James TY, Mastitsky SE, Wurdak E, Giamberini L, Gaylo MJ, Nemeth MJ (2014) Aquastella gen. nov.: a new genus of saprolegniaceous oomycete rotifer parasites related to Aphanomyces, with unique sporangial outgrowths. Fungal Biol 118:544-558
Muraosa Y, Morimoto K, Sano A, Nishimura K, Hatai K (2009) A new peronosporomycete, Halioticida noduliformans gen. et sp. nov., isolated from white nodules in the abalone Haliotis spp. from Japan. Mycosci 50:106-115

Robideau GP, De Cock AW, Coffey MD, Voglmayr H, Brouwer H, Bala K, Chitty DW, Desaulniers N, Eggertson QA, Gachon CM, Hu CH, Kupper FC, Rintoul TL, Sarhan E, Verstappen EC, Zhang Y, Bonants PJ, Ristaino JB, Levesque CA (2011) DNA barcoding of oomycetes with cytochrome $\mathrm{c}$ oxidase subunit I and internal transcribed spacer. Mol Ecol Resour 11:1002-1011

Ronquist F, Teslenko M, van der Mark P, Ayres DL, Darling A, Hohna S, Larget B, Liu L, Suchard MA, Huelsenbeck JP (2012) MrBayes 3.2: efficient Bayesian phylogenetic inference and model choice across a large model space. Syst Biol 6:539-542

Scherffel A (1925) Endophytische Phycomyceten-Parasiten der Bacillariaceen und einige neue Monadinen. Ein Beitrag zur Phylogenie der Oomyceten (Schroter). Arch Protistenk 52:1-141

Scholz B, Küpper FC, Vyverman W, Karsten U (2016) Effects of eukaryotic pathogens (Chytridiomycota and Oomycota) on marine benthic diatom communities in the Solthörn tidal flat (southern North Sea, Germany). Eur J Phycol 51:253-269

Sekimoto S, Hatai K, Honda D (2007) Molecular phylogeny of an unidentified Haliphthoros-like marine oomycete and Haliphthoros milfordensis inferred from nuclear-encoded small- and largesubunit rRNA genes and mitochondrial-encoded cox2 gene. Mycosci 48:212-221

Sosa ER, Landsberg JH, Stephenson CM, Forstchen AB, Vandersea MW, Litaker RW (2007) Aphanomyces invadens and ulcerative mycosis in estuarine and freshwater fish in Florida. J Aqu An Health 19:14-26

Sparrow FK (1933) Inoperculate chytridiaceous organisms collected in the vicinity of Ithaca, N.Y., with notes on other aquatic fungi. Mycologia 25:513-535

Sparrow FK (1935) Recent contributions to our knowledge of the aquatic Phycomycetes. Biol Rev 10:152-186

Sparrow FK (1936) A contribution to our knowledge of the aquatic Phycomycetes of Great Britain. J Linn Soc London, Bot 50:417-478

Sparrow FK (1942) A classification of aquatic Phycomycetes. Mycologia 34:113-116

Sparrow FK (1943) Aquatic Phycomycetes. Univ. of Michigan Press, Ann Arbor, Michigan, U.S.A.

Sparrow FK (1960) Aquatic Phycomycetes. The University of Michigan Press USA

Stamatakis A (2014) RAxML version 8: a tool for phylogenetic analysis and post-analysis of large phylogenies. Bioinf 30:1312-1313

Steciow MM, Lara E, Paul C, Pillonel A, Belbahri L (2014) Multiple barcode assessment within the Saprolegnia-Achlya clade (Saprolegniales, Oomycota, Straminipila) brings order in a neglected group of pathogens. IMA Fungus 5:439-448

Thines M, Nam B, Nigrelli L, Beakes G, Kraberg A (2015) The diatom parasite Lagenisma coscinodisci (Lagenismatales, Oomycota) is an early diverging lineage of the Saprolegniomycetes. Mycol Prog 14: 75

Thines M, Aoki T, Crous PW, Hyde KD, Lücking R, Malosso E, May TW, Miller AN, Redhead SA, Yurkov AM, Hawksworth DL (2020) Setting scientific names at all taxonomic ranks in italics facilitates their quick recognition in scientific papers. IMA Fungus 11:1-5

Tokunaga Y (1934) Notes on the Lagenidiaceae in Japan. Trans Sapporo Nat Hist Soc 12:119-123

Wang Y, Tian RM, Gao ZM, Bougouffa S, Qian PY (2014) Optimal eukaryotic $18 \mathrm{~S}$ and universal $16 \mathrm{~S} / 18 \mathrm{~S}$ ribosomal RNA primers and their application in a study of symbiosis. PLoS ONE 9:e90053

West W, West GS (1906) A comparative study of the plankton of some Irish lake. Trans R Irish Acad Dublin 33:77-116 
Wolinska J, Giessler S, Koerner H (2009) Molecular identification and hidden diversity of novel Daphnia parasites from European lakes. Appl Env Microbiol 75:7051-7059

Zopf W (1878) Über einem neuen parasitischen Phycomyceten. Mitt.V. Prov. Brandenburg 20(77):7
Zopf W (1884) Zur Kenntniss der Phycomyceten. I. Zur Morphologie und Biologie der Ancylisteen und Chytridiaceen. Nov Act Acad Caes Leopoldino-Carolinae Germ Nat Cur 47:143-236

Publisher's note Springer Nature remains neutral with regard to jurisdictional claims in published maps and institutional affiliations. 